\title{
WHICH ONE TO CHOOSE MULTI FOCUS OR TRADE-OFF AMONG COMPETITIVE PRIORITIES? EVIDENCE FROM FINNISH SMEs
}

\author{
Binod Timilsina, Nina Forsén, Josu Takala, Nurul Aida Abdul Malek \\ Department of Production, University of Vaasa, Finland \\ Corresponding author: \\ Binod Timilsina \\ Department of Production \\ University of Vaasa \\ Wolffintie 34, 65200 Vaasa, Finland \\ phone: (+358) 466237496 \\ e-mail: binod.timilsina@uwasa.fi
}

Received: 4 January 2016

Accepted: 22 February 2016

\begin{abstract}
This paper examines the relationship between business environment, competitiveness and firm performance considering a survey data from three consecutive years: 2013-2015. The comparative analysis showed that over these years business environment, competitiveness and firm performance of Finnish SMEs are slowly deteriorating. Results from correlation analysis revealed that business environment, competitiveness and firm performance are positively correlated. However, the relationships between these variables are not consistent in respect to competitive priorities indicating a dynamic nature of cost, quality, time, and flexibility dimensions. Besides these findings our analysis acknowledged that to improve firm performance, irrespective to the choice of competitive priority, SMEs should pay more attention to their competitiveness rather than blaming the business environment. The paper concludes that simultaneous use of competitive priority dimensions might be more favorable as a source of competitiveness and competitive advantage to improve firm performance. However, the managers are encouraged to compare the results, findings and concepts presented in this paper among themselves and comprehend the specific answer to the question posed in the title.
\end{abstract}

KEYWORDS

business environment, competitiveness, firm performance, competitive priority, sustainable competitive advantage.

\section{Introduction}

Literature in operations strategy has emphasized business environment and competitiveness as a prime suspect of firm performance. Here, business environment refers to the external business uncertainty [1] meaning how private investor and business developer perceive business environment for investment and business development while competitiveness refers to the ability of a firm to gain better sales and market share, lower cost, higher productivity and profitability [2] in comparison to its competitors. To remain competitive, survive and grow in a rapidly changing environment, a firm needs to be adaptive to the environmental change $[3,4]$. According to [5] a firm can adapt to the changing business environment through strategic change. In business practices the strategic changes are highly influenced by competitive priorities namely cost, quality, time and flexibility. Irrespective of the business environment a firm competes in the market place through competitiveness which is assumed to be gained either through tradeoff between the dimensions of competitive priority or through cumulative use of competitive priority dimensions. Here, we define cumulative use as to enhance multiple capabilities concurrently [6, pp. 12] in other words simultaneous use of competitive dimensions i.e. multi focus competitive strategy. Both thoughts are equally emphasized in literature [e.g. 610]. Also, literature on strategy has emphasized com- 
petitive priority not only as a source of competitive advantage [11] but also as an effective tool in managing rapidly changing business environments [7]. Business environment, competitiveness, competitive priority, and firm performance are therefore interesting to business practitioner and academic researcher. Previous empirical findings have also revealed links between business environment and firm performance and claimed that the choice of competitive priorities significantly affects business performance [1215]. Questions like: Does the relationship between business environment, competitiveness and firm performance vary with the choice of competitive priority? and - How does the competitive priority over time impact the relationship between business environment, competitiveness and firm performance? has however been given limited importance in current literature. In addition we argue that cumulative use of cost, quality, time, and flexibility dimensions is more favorable as a source of competitiveness and competitive advantage to improve firm performance. According to [16] the relationship between competitive priorities and firm performance can be better understood by considering longitudinal data; also the competitive priorities (cost, quality and time) are multidimensional construct and shows complex dynamic hierarchy over time [17]. Therefore, in this study, we examine the relationship between business environment, competitiveness and firm performance in the context of competitive priority considering survey data from 2013-2015.

The objectives of this exploratory study are: to identify the relationship between business environment, competitiveness and firm performance, and to identify the hierarchy of importance between competitiveness and business environment for improving firm performance. For the purpose perceptual data collected by Collector Bank Ab (a credit company, formerly known as Collector Finland Oy) from Finnish SMEs are considered in this research. Also this research believes that managers' perceptions are sufficient indicators to investigate the relationship between business environment, competitiveness and firm performance and hence to understand the impact of competitive priority over time in the relationship between these variables. This research aims to contribute the literature in operations strategy and shed light on the importance of business environment and competitiveness on firm's performance. Also the research aims to provide guidelines for managers in reviewing and selecting competitive priority in regards to changing business environment in order to improve firm's competitiveness and performance. The paper specifically tries to answer the question raised in the title; however, the managers are encouraged to compare the results, findings and concepts presented in this paper among themselves and comprehend specific answer to the question posed in the title.

\section{Literature review and hypothesis}

The basic model of this research is presented in Fig. 1, which illustrates the relationship between business environment, competitiveness and firm performance.

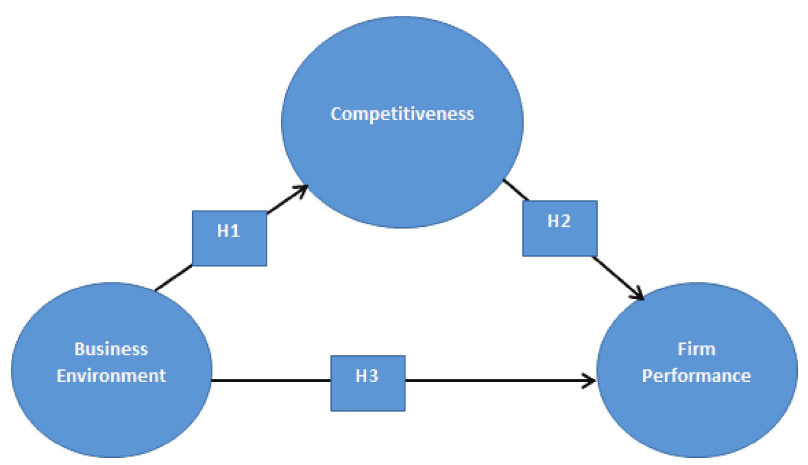

Fig. 1. Research concept.

In this model business environment is linked to competitiveness and firm performance. We hypothesize that business environment is positively linked to firms' competitiveness and realized firm performance. Likewise, we also hypothesize that firms' competitiveness is positively linked to firm performance. The concepts included in this research (Fig. 1, above) are discussed in detail as follows:

\section{Business environment and competitiveness}

In the literature competitiveness has been defined at three different levels: firm, industry, and national or regional level [18]. Competitiveness at firm level is the ability of a firm to design, produce and market its products at a competitive price and quality in comparison to its competitors with reasonable profit [19]. Industrial competitiveness can be defined as the overall performance of a firm in comparison to its competitors within the industry $[20,21]$. Similarly, national competitiveness can be defined as a nation's capability to maintain an advantageous position in the global market in the long run by means of key industrial area [22]. According to [23, p. 58] competitiveness is relative and not absolute. It depends on shareholder and customer values, financial strength which determines the ability to act and react within the competitive environment and the potential of people and technology in implementing the 
necessary strategic changes. Competitiveness is not only growth or economic performance but should also consider factors like business environment, quality of life, technology, and knowledge. The above mentioned factors have been termed soft factors of competitiveness by [18].

Following these definitions of competitiveness it is imperative that competitiveness and business environment are complementary to each other. Consequently, theories like resource based view and institutional theory asserts that business environment and competitiveness are interdependent. After all it is resources and capabilities that help to maintain differentiation in market and determine competitive positions and competitiveness. According to [24] resources, market conditions, and industry network influence competitiveness. According to [22] demand conditions, factor input conditions, firm's strategic context and related industries constitute the microeconomic business environment which ultimately affects productivity that determines competitiveness. Innovation, knowledge and conditions of the business environment are related to competitiveness [25].

Due to the changing nature of the business environment companies are forced to change their competitive capabilities. Quality has for example become more important than cost and economies of scale has shifted to economies of scope [26]. Firms' internal resources are however in many cases insufficient to meet the needs of changing business environments and exploit new opportunities. Under such circumstances competing and cooperating relationships among firms is important to improve competitiveness [24]. According to [27] in complex and uncertain environments innovation capability enhances competitiveness. In comparison to large firms SMEs are more affected by the external environments which influence their competitiveness [28]. The theoretical arguments discussed above strongly suggest a positive influence of business environment on a firm's competitiveness. Based on this discussion we propose the following hypothesis:

H1: Business environment is positively related to competitiveness

\section{Competitiveness and firm performance}

The resource based view of the firm has emphasized that sustainable competitive advantage is the result of resources and organizational capabilities that are valuable, rare, inimitable and nonsubstitutable [29]. Such resources and organizational capabilities not only make firms operations efficient [30] but they also make a firm competitive in the market. Therefore, the relationship between firms' competitiveness and firm performance has been examined in terms of different organizational capabilities as for example: knowledge management [31, 32], use of modern technology, innovation capability [33, 34], organizational learning [35], marketing capability [36], and many more. According to [22] a firm can improve its organizational performance and consequently its competitiveness either through low cost or differentiated products. All these different views on sources of competitiveness not only indicate that competitiveness is a multidimensional construct but also show that the majority of researches dealing with the impact of competitiveness on firm performance are indirectly expressed in the literature. Furthermore, a large body of literature has shown that organizational capabilities enhance a firm's competitiveness which has significant influence on firm performance [e.g. 37-39]. According to [40] innovative use of cross-functional teams leads to better operational performance. There are also extents of literature that show mixed results; for example in their study [41] found that innovation was weakly linked to sales. In a similar manner, [42] found no relationship between information technology capability and firm performance; according to the authors similar studies in previous years have obtained a positive link between information technology and firm performance. Thus it is reasonable to say that different resources and capabilities signify the competitiveness which ultimately defines firm performance. According to [43] competitive price, wide product range, better distribution and marketing are the key terms to define competitiveness. However, competitiveness is a means through which a firm can improve its performance. Based on this discussion we propose the following hypothesis:

$\mathrm{H} 2$ : Competitiveness is positively related to firm performance.

\section{Business environment and firm performance}

In the literature business environment has been defined in various forms for example [44] defines business environment as managerial perception of decision making and defining firm's objective where information flows from business environment while [45] defines business environment as social and physical factors which needs to be taken into account in decision making. However, firms are environment dependent and serve the environment within which they operate $[46,47]$. This means that the strategic process adopted by a firm is determined by the nature of the firm's operating environment [48] and performance is the result of the interaction between a firm and its operating environment [49]. Literature 
in the school of contingency management has emphasized the role of business environment on firm performance [e.g. 50-53]. Likewise, some authors have argued that a firm with better environmental fit shows higher performance in comparison to firms with lower environmental fit $[54,55]$. Here, environmental fit is intended to convey a sense of matching between a firm and the business environment [56]. However, firms operating in the same business environment and within the same industry may perceive identical environments differently [55]. Because of this difference in environmental perception individual firms react differently and show different adaptive patterns [3] and subsequent performance. In other words, business environment and strategy adoption are linked to firm performance and has been one of the core research topics in strategic literature [57]. At the same time the effectiveness of a strategy adopted by a firm depends on characteristics of the business environment [58]. Hence, to survive, compete and grow a firm needs to align itself with the changing environment $[3,4]$ because business environment influences strategic choice and affect firm performance. Also this view is supported by [59] and says earning of long term profits are inherent in external environment. This indicates that business environment is an important antecedent of firm performance. Therefore, we hypothesize that:

H3: Business environment is positively related to firm performance.

\section{Methodology}

\section{Measures}

The survey questionnaire contained 27 items. However, we limited ourselves to items directly related to the scope of this research. This research did not consider the traditional indicators of competitiveness (e.g. growth rate, innovation, market share, technology etc.), business environment (complexity, dynamism, munificence) and firm performance (e.g. return on assets, return on investment, profit margin, net profit etc.). However, the considered indicator for each variable encapsulates how the evolutions of traditional indicators are perceived by survey respondent. All constructs were measured on five point Likert scale i.e. $1=$ strongly disagree to $5=$ strongly agree. The reliability coefficient Cronbach alpha found to be 0.780 (2013), 0.797 (2014), and 0.812 (2015) thus provides the satisfactory level of reliability. In a similar manner the competitive priorities (cost, quality, time, and flexibility) were measured with the question: - What is the most important factor of success in your field / of the competitive ad- vantage generated? And the respondents were asked to choose the best match according to their strategic focus. This is because the strategic weight given by a firm to a competitive priority not only reflects the degree of emphasis provided to either of the competitive priorities [12] but also the strategic orientation [60]. The different measures considered for this research are as outlined below:

\section{Competitiveness}

In literature there exist a number of variables to measure competitiveness as for example: productivity, financial performance and non-financial performance. According to [61] productivity and competitiveness has often been wrongly interpreted in literature and used interchangeably. The authors provide a clear distinction between these two terms and say that productivity is the firm's internal capacity while competitiveness represents the position of a firm in respect to its competitors. Referring to the European Management Forum 1984 [62, p. 176] defines competitiveness as the immediate and future ability of, and opportunities for, entrepreneurs to design, produce and market goods worldwide whose price and nonprice qualities form a more attractive package than those of foreign and domestic competitors. Competitiveness is a resource intensive process which makes it difficult to measure [63], also competitiveness cannot be measured through single measure [62]. Therefore, instead of using commonly used financial and nonfinancial measures of competitiveness in the survey we asked respondent to express their perception on firm competitiveness in general. For the purpose of this paper we considered the following measures in capturing the firm level competitiveness.

- How do you perceive your competitiveness?

- How has your competitiveness changed in the last five years?

- How do you expect your competitiveness to change in the following year?

\section{Business environment}

In [13] authors has emphasized the importance of perceived business environment; according to the authors strategic behavior of a firm is influenced by managerial perception of the business environment. Likewise, [1] also has highlighted the importance of perceived business environment in investment decisions. Following this argument, we measured business environment through managerial perception. The different measures of business environment considered in this research are as follows:

- How do you perceive the business environment for SMEs in Finland? 
- How has the business environment changed in the last five years?

- How do you expect the business environment to change in the following year?

\section{Firm performance}

Firm performance can be measured either through financial or non-financial measures. However, performance measures like return on investment, profit margin, sales and market share are not appropriate in comparing inter-firm performance due to different firm sizes and accounting principles. Therefore, self-perceived firm performance better reflects firm performance [64]. Hence, in this study instead of following traditional financial and non-financial measures of firm performance we measure firm performance through managerial perception. The different measures of firm performance considered in this research are as follows:

- How is your company's financial situation at the moment?

- How has your company's financial situation changed in the last few years?

- How do you expect your financial situation to change in the following year?

\section{Sample and data collection}

Finnish SMEs are the source of primary data for this research. The data has been collected by the credit company Collector Bank Ab in the first half of each year during the time period 2013-2015 through online survey. The questionnaires were developed by Collector Bank Ab themselves and include considerable details on the features of business environment, competitiveness and firm performance. The survey participants have been varying each year; 467 compa- nies participated in online survey in 2013, 596 companies in 2014, and 171 companies in 2015. However, 21 respondents in 2013 and 13 respondents in 2014 did not mention their competitive priorities so these respondents were not included in the analysis. Similarly, in the year 2015 survey 68 respondent selected more than one variable as their competitive priority. The responses from these respondents were analyzed to support the argument that cumulative use of cost, quality, time, and flexibility dimensions is more favorable as a source of competitiveness and competitive advantage to improve firm performance. Hence, to gain and sustain competitiveness and competitive advantage. The Fig. 2 below summarizes the participation of respondents according to their position in the company and the company's turnover. This survey does not represent an adequate number of respondents considering the entire population of SMEs in Finland; however, this research believes that the obtained response number is enough for exploratory analysis of business environment, competitiveness and performance of SMEs in Finland.

\section{Method of analysis}

The study used SPSS software to analyze the data obtained from the survey. The data was mainly analyzed in two forms. First, a cross comparison between the data from 2013-2015 was made for general analysis. Second, a widely accepted Pearson correlation test was carried out to verify the proposed relationship between business environment, competitiveness and firm performance. In addition, the survey data was divided into the four groups: cost, quality, time and flexibility which were analyzed through Pearson correlation test in order to answer the research question and meet the research objectives.

Your position in the company? / Your company's turnover category million. EUR:

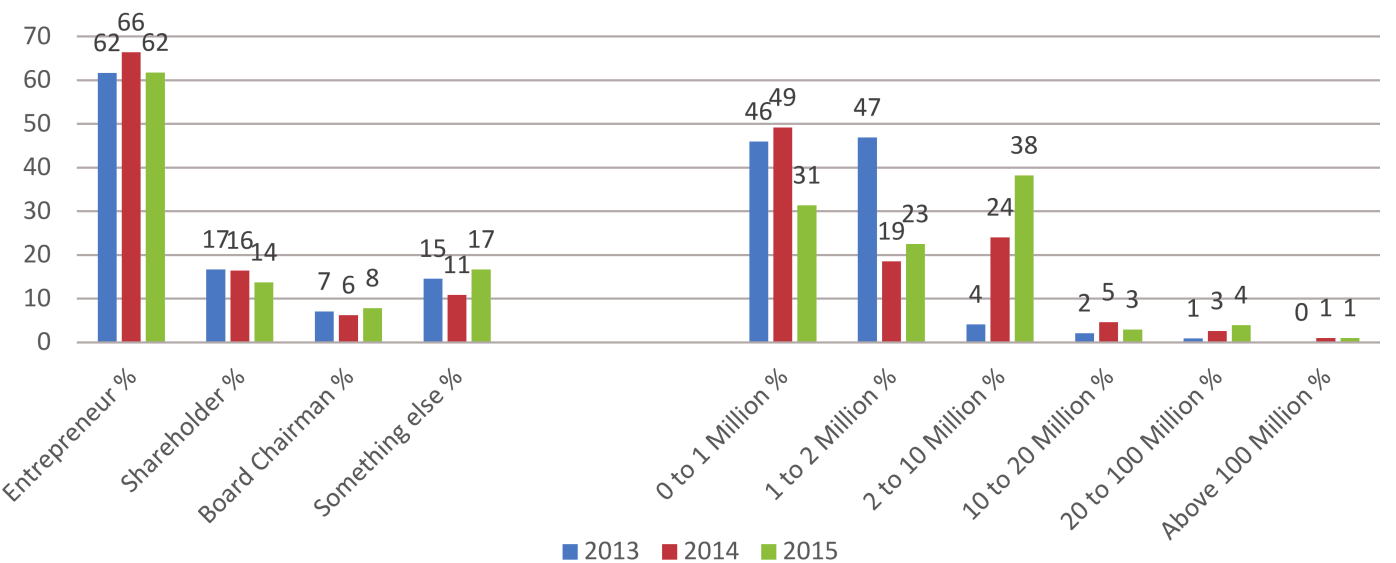

Fig. 2. Participation of respondents according to their position and the company's turnover. 


\section{Results and findings}

\section{Comparative analysis: Year 2013-2015}

The Table 1 below summarizes the strategic focus of Finnish SMEs during the year 2013-2015. Here, strategic focus represents the strategic priority given to either dimensions of cost, quality, time, and flexibility. As shown in Table 1, quality remained the most common competitive priority in the years 2013 2015 , followed by cost, flexibility and finally time. Emphasis on cost increased in 2015 while emphasis on time saw a decrease following 2013.

Table 1

Strategic focus of Finnish SMEs: 2013-2015.

\begin{tabular}{c|c|c|c}
\hline Competitive priorities & 2013 & 2014 & 2015 \\
\hline $\mathrm{Q}[\%]$ & 52.6 & 56.6 & 49.4 \\
\hline $\mathrm{C}[\%]$ & 32.4 & 32.1 & 39.2 \\
\hline $\mathrm{T}[\%]$ & 15.0 & 11.2 & 11.4 \\
\hline $\mathrm{F}[\%]$ & 23.8 & 23.7 & 22.5 \\
\hline
\end{tabular}

In the similar manner, respondents were more inclined to evaluate the current business environment as poor or very poor and less inclined to evaluate it as good in 2015 than they were in the two preceding years. Time and flexibility focused firms had the most positive outlook on the business environment. In regards to the change in the business environment, in the last five years, the most common answer in all three years (2013-2015), irrespective of the competitive priority, was that the business environment had worsened slightly. Expectations regarding the future change in the business environment remained fairly unchanged during the time period; most respondents expected the business environment to stay the same or undergo slight changes. Cost focused firms had the least positive outlook on the future state of the business environment throughout the time period.

The competitiveness of Finnish SMEs had likewise declined in the years 2013-2015; more respondents chose the answer fair and fewer claimed that their competitiveness was good in 2015. Cost focused firms were the least inclined to perceive their competitiveness as good. A slight overall deterioration was also discernible for the change in competitiveness during the last few years. Expectations regarding the future change in the competitiveness remained fairly unchanged during the time period; about half of respondents expected their own competitiveness to stay the same during the following year while around 30 percent expected it to improve slightly.

The financial situation of Finnish SMEs had similarly deteriorated during the researched time period; more respondents claimed that their financial situation was weak, fair or satisfactory in 2015 while fewer claimed it was good or excellent. Developments in the financial situations of Finnish SMEs were also increasingly negative irrespective of the competitive priorities. The respondents expected their financial situation to continue developing in the same manner in the following years as it had in the last few years.

From this follows that out of the competitive priorities, time focused firms' had an in general over average performance throughout the time period 20132015 while cost focused firms' performance was the weakest. Quality focused firms placed in the middle performance wise alongside flexibility focused firms.

\section{Correlation analysis}

The calculated values of Pearson correlation, level of significance with sample numbers are presented in the Tables 2, 3, and 4 . The correlation results presented in Tables 2, 3, and 4 is irrespective to competitive priorities. This means the sample represents the entire respondent either they choose cost, quality, time, flexibility or a combination of these. In order to make comparative analysis on the relationship between business environment, competitiveness, and firm performance the correlation between these variables were calculated on yearly basis.

The correlation test results in Tables 2, 3, and 4 shows positive and significant relationship between business environment, competitiveness, and firm performance over the years 2013-2015. Comparing the value of Pearson correlation (Tables 2, 3, and 4) shows that throughout the years 2013-2015, H1 (Business environment and competitiveness) is the most significant, the values of Pearson correlation was found to be $0.577,0.558$, and 0.535 during years 2013, 2014, and 2015 respectively. Likewise, H3 (Business environment and Firm performance) is the least significant while $\mathrm{H} 2$ (competitiveness and firm performance) remain in the middle, throughout the years 2013-2015 (see Tables 2, 3, and 4). This suggests that to improve firm performance, irrespective to the choice of competitive priority, SMEs should pay more attention to their competitiveness rather than blaming the business environment. 
Table 2

Correlation analysis (irrespective to competitive priorities): 2013.

\begin{tabular}{|c|c|c|c|c|}
\hline Variables & & Firm performance & Business Environment & Competitiveness \\
\hline \multirow{3}{*}{ Firm performance } & Pearson correlation & 1 & & \\
\hline & Sig. (2-tailed) & - & & \\
\hline & $\mathrm{N}$ & 446 & & \\
\hline \multirow{3}{*}{ Business Environment } & Pearson correlation & $.363^{* *}$ & 1 & \\
\hline & Sig. (2-tailed) & .000 & - & \\
\hline & $\mathrm{N}$ & 446 & 446 & \\
\hline \multirow{3}{*}{ Competitiveness } & Pearson correlation & $.487^{* *}$ & $.577^{* *}$ & 1 \\
\hline & Sig. (2-tailed) & .000 & .000 & - \\
\hline & $\mathrm{N}$ & 446 & 446 & 446 \\
\hline
\end{tabular}

Table 3

Correlation analysis (irrespective to competitive priorities): 2014 .

\begin{tabular}{|c|c|c|c|c|}
\hline Variables & & Firm performance & Business Environment & Competitiveness \\
\hline \multirow{3}{*}{ Firm performance } & Pearson correlation & 1 & & \\
\hline & Sig. (2-tailed) & - & & \\
\hline & $\mathrm{N}$ & 583 & & \\
\hline \multirow{3}{*}{ Business Environment } & Pearson correlation & $.415^{* *}$ & 1 & \\
\hline & Sig. (2-tailed) & .000 & - & \\
\hline & $\mathrm{N}$ & 583 & 583 & \\
\hline \multirow{3}{*}{ Competitiveness } & Pearson correlation & $.533^{* *}$ & $.558^{* *}$ & 1 \\
\hline & Sig. (2-tailed) & .000 & .000 & - \\
\hline & $\mathrm{N}$ & 583 & 583 & 583 \\
\hline
\end{tabular}

Table 4

Correlation analysis (irrespective to competitive priorities): 2015.

\begin{tabular}{|c|c|c|c|c|}
\hline Variables & & Firm performance & Business Environment & Competitiveness \\
\hline \multirow{3}{*}{ Firm performance } & Pearson correlation & 1 & & \\
\hline & Sig. (2-tailed) & - & & \\
\hline & $\mathrm{N}$ & 102 & & \\
\hline \multirow{3}{*}{ Business Environment } & Pearson correlation & $.372^{* *}$ & 1 & \\
\hline & Sig. (2-tailed) & .000 & - & \\
\hline & $\mathrm{N}$ & 102 & 102 & \\
\hline \multirow{3}{*}{ Competitiveness } & Pearson correlation & $.532^{* *}$ & $.535^{* *}$ & 1 \\
\hline & Sig. (2-tailed) & .000 & .000 & - \\
\hline & $\mathrm{N}$ & 102 & 102 & 102 \\
\hline
\end{tabular}

The Table 5 below represents values of Pearson correlation according to competitive priorities i.e. cost, quality, time, and flexibility over the years 2013-2015. Here the respondents are first categorized on the basis of competitive priority before calculating correlation between business environment, competitiveness, and firm performance over the years 20132015. The results presented in Table 5 below shows that the relationships between these variables are inconclusive in respect to competitive priorities.
Comparing the value of Pearson correlation (table 5), it shows that throughout the years 2013-2015, some of the hypotheses are fully supported while others are partially supported and even some of the hypotheses are rejected. H1, H2, and H3 are for instance rejected in case of time focused firms in 2015 with $r=0.457, r=0.295$, and $r=-0.066$ respectively. Similarly, H3 is rejected in case of cost focused firm in 2015 with $r=0.178$ and time focused firm in 2014 with $r=0.136$. Also the result shows that 
there is a notable fluctuation in the value of Pearson correlation showing significant differences in the levels of correlation between business environment, competitiveness and firm performance. The correlation analysis presented in Table 5 indicates that competitive priorities are dynamic in nature. Therefore, focusing on a single competitive priority may not be favorable for sustaining competitiveness.

In the similar manner, Table 6 below shows the correlation analysis of multi focused firms in 2015. Here, multi focus represents the respondent who selected more than one competitive priority as their main focus. During the year 2015 there were 68 respondents who claimed that they focus on different competitive priorities simultaneously however during the years 2013 and 2014 none of the respondent claim for multi focus competitive priorities. These 68 respondents from the survey of 2015 are considered as multi focus group in calculating the values of Pearson correlation between business environment, competitiveness, and firm performance.
The results (Table 6) indicate that all respective relationships (H1-H3) under multi focused competitive priority are positively significant. The multifocused group is further explored through four different angles; cost, quality, time and flexibility. The correlation values of each angle are calculated and then compared according to their respective hypothesis. The Table 7 below shows the results of correlation analysis in regards to different combination of competitive priority as indicated by respondent. As for example, combination with cost means cost is common with quality, time, and flexibility while combination without cost means cost is excluded in either combination of quality, time, and flexibility. And the different category (i.e. combination with quality, combination without quality, combination with time, combination without time, combination with flexibility, combination without flexibility) presented in Table 7 follows the same pattern. All together there were eight different combinations as shown in Table 7 .

Table 5

Correlation analysis (with respect to competitive priority): 2013-2015.

\begin{tabular}{|c|c|c|c|c|c|c|c|c|c|c|c|c|}
\hline & \multicolumn{12}{|c|}{ Pearson correlation } \\
\hline & \multicolumn{4}{|c|}{2013} & \multicolumn{4}{|c|}{2014} & \multicolumn{4}{|c|}{2015} \\
\hline & ن & 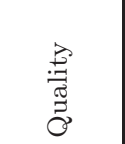 & $\underset{\Xi}{\stackrel{\Xi}{\mid g}}$ & 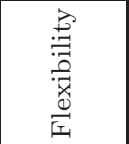 & ن & $\begin{array}{l}\stackrel{\vec{\Xi}}{: \widetilde{\Xi}} \\
\underset{\Im}{\Xi}\end{array}$ & $\underset{:}{\stackrel{\Xi}{\Xi}}$ & 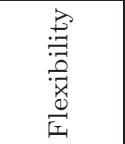 & نे & 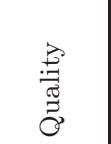 & $\underset{\mathscr{E}}{\stackrel{\Xi}{E}}$ & 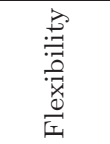 \\
\hline H1 (BE-C) & $\begin{array}{c}0.474^{* *} \\
\mathrm{~N}=110\end{array}$ & $\begin{array}{c}0.454^{* *} \\
\mathrm{~N}=179\end{array}$ & $\begin{array}{l}0.512^{* *} \\
\mathrm{~N}=51\end{array}$ & $\begin{array}{c}0.439^{* *} \\
\mathrm{~N}=106\end{array}$ & $\begin{array}{c}0.529^{* *} \\
\mathrm{~N}=143\end{array}$ & $\begin{array}{c}0.518^{* *} \\
\mathrm{~N}=252\end{array}$ & $\begin{array}{l}0.528^{* *} \\
\mathrm{~N}=50\end{array}$ & $\begin{array}{c}0.483^{* *} \\
\mathrm{~N}=138\end{array}$ & $\begin{array}{c}0.435^{*} \\
\mathrm{~N}=31\end{array}$ & $\begin{array}{l}0.490^{* *} \\
\mathrm{~N}=39\end{array}$ & $\begin{array}{c}0.457 \\
\mathrm{~N}=9\end{array}$ & $\begin{array}{c}0.647^{*} \\
\mathrm{~N}=23\end{array}$ \\
\hline H2 (C-FP) & $\begin{array}{c}0.580^{* *} \\
\mathrm{~N}=110\end{array}$ & $\begin{array}{c}0.531^{* *} \\
\mathrm{~N}=179 \\
\end{array}$ & $\begin{array}{l}0.570^{* *} \\
\mathrm{~N}=51\end{array}$ & $\begin{array}{c}0.515^{* *} \\
\mathrm{~N}=106\end{array}$ & $\begin{array}{c}0.556^{* *} \\
\mathrm{~N}=143\end{array}$ & $\begin{array}{c}0.612^{* *} \\
\mathrm{~N}=252 \\
\end{array}$ & $\begin{array}{l}0.362^{* *} \\
\mathrm{~N}=50\end{array}$ & $\begin{array}{c}0.367^{* *} \\
\mathrm{~N}=138 \\
\end{array}$ & $\begin{array}{l}0.782^{* *} \\
\mathrm{~N}=31\end{array}$ & $\begin{array}{l}0.466^{* *} \\
\mathrm{~N}=39\end{array}$ & $\begin{array}{c}0.295 \\
\mathrm{~N}=9 \\
\end{array}$ & $\begin{array}{c}0.368 \\
\mathrm{~N}=23\end{array}$ \\
\hline H3 (BE-FP) & $\begin{array}{c}0.178 \\
\mathrm{~N}=102\end{array}$ & $\begin{array}{c}0.328^{*} \\
\mathrm{~N}=179\end{array}$ & $\begin{array}{l}0.375^{* *} \\
\mathrm{~N}=51\end{array}$ & $\begin{array}{c}0.450^{* *} \\
\mathrm{~N}=106\end{array}$ & $\begin{array}{c}0.406^{* *} \\
\mathrm{~N}=143\end{array}$ & $\begin{array}{c}0.439^{* *} \\
\mathrm{~N}=252\end{array}$ & $\begin{array}{c}0.136 \\
\mathrm{~N}=50\end{array}$ & $\begin{array}{c}0.352^{* *} \\
\mathrm{~N}=138\end{array}$ & $\begin{array}{l}0.573^{* *} \\
\mathrm{~N}=31\end{array}$ & $\begin{array}{c}0.212 \\
\mathrm{~N}=39\end{array}$ & $\begin{array}{l}-.066 \\
\mathrm{~N}=9\end{array}$ & $\begin{array}{c}0.437^{*} \\
\mathrm{~N}=23\end{array}$ \\
\hline
\end{tabular}

*. Correlation is significant at the 0.05 level (2-tailed). **. Correlation is significant at the 0.01 level (2-tailed). $\mathrm{BE}=$ Business environment, $\mathrm{C}=$ Competitiveness, $\mathrm{FP}=$ Firm performance

Table 6

Correlation analysis (with respective to multi focus competitive priorities): 2015 .

\begin{tabular}{|c|c|c|c|c|}
\hline Variables & & Firm performance & Business Environment & Competitiveness \\
\hline \multirow{3}{*}{ Firm performance } & Pearson correlation & 1 & & \\
\hline & Sig. (2-tailed) & - & & \\
\hline & $\mathrm{N}$ & 68 & & \\
\hline \multirow{3}{*}{ Business Environment } & Pearson correlation & $.395^{* *}$ & 1 & \\
\hline & Sig. (2-tailed) & .001 & - & \\
\hline & $\mathrm{N}$ & 68 & 68 & \\
\hline \multirow{3}{*}{ Competitiveness } & Pearson correlation & $.445^{* *}$ & $.427^{* *}$ & 1 \\
\hline & Sig. (2-tailed) & .000 & .000 & - \\
\hline & $\mathrm{N}$ & 68 & 68 & 68 \\
\hline
\end{tabular}

**. Correlation is significant at the 0.01 level (2-tailed). 
Management and Production Engineering Review

Table 7

Correlation analysis (based on multi-focused competitive priority with different combination): 2015.

\begin{tabular}{|c|c|c|c|c|c|c|}
\hline & \multicolumn{6}{|c|}{ Pearson correlation } \\
\hline & \multicolumn{2}{|c|}{$\mathrm{H}_{1}(\mathrm{BE}-\mathrm{C})$} & \multicolumn{2}{|c|}{$\mathrm{H}_{2}(\mathrm{C}-\mathrm{FP})$} & \multicolumn{2}{|c|}{$\mathrm{H}_{3}(\mathrm{BE}-\mathrm{FP})$} \\
\hline & $\mathrm{r}$ & $\mathrm{N}$ & $\mathrm{r}$ & $\mathrm{N}$ & $\mathrm{r}$ & $\mathrm{N}$ \\
\hline Combination with cost & $.360^{*}$ & 31 & $.562^{* *}$ & 31 & $.399^{*}$ & 31 \\
\hline Combination without cost & $.670^{* *}$ & 36 & $.602^{* *}$ & 36 & $.535^{* *}$ & 36 \\
\hline Combination with quality & $.629^{* *}$ & 53 & $.581^{* *}$ & 53 & $.526^{* *}$ & 53 \\
\hline Combination without quality & 0.27 & 14 & $.731^{* *}$ & 14 & 0.43 & 14 \\
\hline Combination with time & $.577^{* *}$ & 31 & $.591^{* *}$ & 31 & $.516^{* *}$ & 31 \\
\hline Combination without time & $.504^{* *}$ & 36 & $.632^{* *}$ & 36 & $.408^{*}$ & 36 \\
\hline Combination with flexibility & $.501 * *$ & 52 & $.562^{* *}$ & 52 & $.437^{* *}$ & 52 \\
\hline Combination without flexibility & $.696^{* *}$ & 15 & $.753^{* *}$ & 15 & $.643^{* *}$ & 15 \\
\hline
\end{tabular}

The result indicates that nearly all respective relationships under multi-focused competitive priority are positively significant (see Table 7) and also in majority their correlation values are greater than those who chose single-focused competitive priority (see Table 5 and Table 7). This suggests that multifocused competitive priority is a potential contributing factor to improve overall internal as well as external performance of a firm.

\section{Discussion and conclusions}

The result from the study showed that the business environment, competitiveness and firm performance of Finnish SMEs are slowly deteriorating over the years 2013-2015. However, the respondents were hopeful regarding the future development throughout the researched time period. Likewise, the correlation test results showed positive and significant relationships between business environment, competitiveness and firm performance. However, comparing the value of Pearson correlation (Tables 2, 3, and 4) it showed that throughout the years 2013-2015, H1 (business environment and competitiveness) was the most significant and H3 (business environment and Firm performance) was the least significant while H2 (competitiveness and firm performance) remained in the middle. This implies that in order to improve firm performance one should stop blaming the business environment and instead put more emphasis on competitiveness.

The strategic management literature has highlighted that gaining and sustaining competitive advantage requires a firm to change its strategies according to the nature of changing business environments [5]. This means that to gain and sustain com- petitive advantage a firm should be able to set their strategic priorities in such a way that it allows the firms to differentiate itself from competitors in the marketplace on a continuous basis. According to [65] cost, quality, time, and flexibility are the key priorities through which a firm competes and differentiate itself in the market. Some authors have found the support for trade-off between competitive priorities [e.g. 6] while others have argued for multi focus [e.g. 9, 10]. Reviewing the two decades of empirical research in operations strategy [66] argues against the trade-off model and says on average manufacturers do not claim that they have experienced tradeoff among competitive priorities. In this context, our study reveals that the relationships between business environment, competitiveness and firm performance are inconclusive in respect to competitive priorities and time (Table 5); correlation analysis with respect to competitive priorities shows a significant difference in the value of correlation and the level of significance. Not all the proposed hypotheses are accepted in respect to competitive priorities (see Table 5) indicating a dynamic nature of cost, quality, time, and flexibility dimensions. Furthermore, in 2015, $40 \%$ of survey respondents selected more than one variable as their competitive priority. In a similar manner comparing the correlation analysis presented in Table 5 and Table 6 shows that the correlation between business environment, competitiveness and firm performance are more significant in case of multi focus competitive priority than in case of single focus competitive priority. Therefore, it is reasonable to say that the survey results and the correlation analysis (Tables 5, 6 and 7) support the notion that cumulative use of competitive priority dimensions might be a more favorable source of competitiveness, competitive advantage and consequently improve firm perfor- 
mance, than a trade-off between the competitive priorities. In other words, operations strategy needs to be multi focused i.e. the combination of competitive priorities needs to be changed in the time rolling basis. In the previous study [67] and [68] also found support for combination of competitive priorities; they pointed out the common possibility of manufacturing companies to simultaneously emphasize different competitive priority, especially those who are lacking of capability to compete within one competitive priority and whose main competitor has been more mature and resourceful.

The study was limited to customers of credit company Collector Bank $\mathrm{Ab}$ and does not represent an adequate number considering the entire population of SMEs in Finland. However, this research believes that the obtained response number is enough for general analysis of business environment, competitiveness and performance of SMEs in Finland. Considering these limitations, we recommend future research to be carried out on larger sample sizes. A comparative study among similar countries (e.g. Scandinavian) would also shed further lights in generalizing the result and findings.

\section{References}

[1] Kocabasoglu C., Prahinski C., Klassen R.D., Linking forward and reverse supply chain investments: the role of business uncertainty, Journal of Operations Management, 25, 6, 1141-1160, 2007.

[2] Cerrato D., Depperu D., Unbundling the construct of firm-level international competitiveness, Multinational Business Review, 19, 4, 311-331, 2011.

[3] Mintzberg H., The fall and rise of strategic planning, Harvard Business Review, 72, 1, 107-114, 1994.

[4] Yauch C.A., Measuring agility as a performance outcome, Journal of Manufacturing Technology Management, 22, 3, 384-404, 2011.

[5] Yi Y., He X., Ndofor H., Wei Z., Dynamic capabilities and the speed of strategic change: Evidence from China, Engineering Management, IEEE Transactions on, 62, 1, 18-28, 2015.

[6] Boyer K.K., Lewis M.W., Competitive priorities: investigating the need for trade-offs in operations strategy, Production and operations management, 11, 1, 9-20, 2002.

[7] Hallgren M., Olhager J., Schroeder R.G., A hybrid model of competitive capabilities, International Journal of Operations \& Production Management, 31, 5, 511-526, 2011.
[8] Xiaosong P.D., Schroeder R.G., Shah R., Competitive priorities, plant improvement and innovation capabilities, and operational performance: A test of two forms of fit, International Journal of Operations \& Production Management, 31, 5, 484-510, 2011.

[9] Takala J., Analysing and synthesising multifocused manufacturing strategies by analytical hierarchy process, International Journal of Manufacturing Technology and Management, 4, 5, 345-355, 2002.

[10] Kathuria R., Competitive priorities and managerial performance: a taxonomy of small manufacturers, Journal of Operations Management, 18, 6, 627$641,2000$.

[11] Prajogo D.I., McDermott P., Examining competitive priorities and competitive advantage in service organisations using Importance-Performance Analysis matrix, Managing Service Quality: An International Journal, 21, 5, 465-483, 2011.

[12] Chi T., Corporate competitive strategies in a transitional manufacturing industry: An empirical study, Management Decision, 48, 6, 976-995, 2010.

[13] Ward P.T., Duray R., Leong G.K., Sum C.C., Business environment, operations strategy, and performance: An empirical study of Singapore manufacturers, Journal of Operations Management, 13, 2, 99-115, 1995.

[14] Wright M., Filatotchev L., Hoskisson R.E., Peng M.W., Strategy in emerging economies: Challenging the conventional wisdom*, Journal of Management Studies, 42, 1, 1-33, 2005.

[15] Kroes J.R., Ghosh S., Outsourcing congruence with competitive priorities: Impact on supply chain and firm performance, Journal of Operations Management, 28, 2, 124-143, 2010.

[16] Miller J.G., Roth A.V., A taxonomy of manufacturing strategies, Management Science, 40, 3, 285-304, 1994.

[17] Corbett C., Wassenhove L.V., Trade-offs? What trade-offs? Competence and competitiveness in manufacturing strategy, California Management Review, 35, 4, 107-122, 1993.

[18] Balkyte A., Tvaronavičiene M., Perception of competitiveness in the context of sustainable development: facets of "sustainable competitiveness", Journal of Business Economics and Management, 11, 2, 341-365, 2010.

[19] Ajitabh A., Momaya K.S., Competitiveness of firms: Review of Theory, Frameworks and Models, Singapore management Review, 26, 1, 45-61, 2004.

[20] Oral M., A methodology for competitiveness analysis and strategy formulation in glass industry, Euro- 
pean Journal of Operational Research, 68, 1, 9-22, 1993.

[21] Maillard P., Focus Series, Competitive Quality Strategy, John Wiley \& Sons, ISBN 978-1-11864429-4, 2013

[22] Porter M., The competitive advantage of nations, New York: Free Press, 1990.

[23] Feurer R., Chaharbaghi K., Defining competitiveness: A holistic approach, Management Decision, 32, 2, 49-58, 1994.

[24] Álvarez I., Marin R., Fonfría A., The role of networking in the competitiveness of firms, Technological Forecasting and Social Change, 76, 3, 410-421, 2009.

[25] Huggins R., Creating a UK Competitiveness Index: Regional and Local Benchmarking, Regional Studies, 37, 1, 89-96, 2003.

[26] Tracey M., Vonderembse M.A., Lim J.S., Manufacturing technology and strategy formulation: keys to enhancing competitiveness and improving performance, Journal of Operations Management, 17, 4, 411-428, 1999.

[27] Castellacci F., Innovation and the competitiveness of industries: Comparing the mainstream and the evolutionary approaches, Technological Forecasting and Social Change, 75, 7, 984-1006, 2008.

[28] Man T.W., Lau T., Chan K.F., The competitiveness of small and medium enterprises: A conceptualization with focus on entrepreneurial competencies, Journal of Business Venturing, 17, 2, 123-142, 2002 .

[29] Barney J., Firm resources and sustained competitive advantage, Journal of management, 17, 1, 99-120, 1991.

[30] Grant R.M., Contemporary strategy analysis: Concepts, techniques, applications (2nd edition), Basil Blackwell Inc., Cambridge, Massachusetts, 1995.

[31] Egbu C.O., Hari S., Renukappa S.H., Knowledge management for sustainable competitiveness in small and medium surveying practices, Structural Survey, 23, 1, 7-21, 2005.

[32] Andreeva T., Kianto A., Does knowledge management really matter? Linking knowledge management practices, competitiveness and economic performance, Journal of Knowledge Management, 16, 4, 617-636, 2012.

[33] Lasagni A., How can external relationships enhance innovation in SMEs? New evidence for Europe*, Journal of Small Business Management, 50 (2), 310339, 2012.
[34] Hashi I., Stojčić N., The impact of innovation activities on firm performance using a multi-stage model: Evidence from the Community Innovation Survey 4 , Research Policy, 42, 2, 353-366, 2013.

[35] Santos-Vijande M.L., López-Sánchez J. Á., Trespalacios J.A., How organizational learning affects a firm's flexibility, competitive strategy, and performance, Journal of Business Research, 65, 8, 10791089, 2012.

[36] Yee K.P., Eze U.C., The influence of quality, marketing, and knowledge capabilities in business competitiveness, International Journal of Innovation and Learning, 11, 3, 288-307, 2012.

[37] Mithas S., Ramasubbu N., Sambamurthy V., How information management capability influences firm performance, MIS quarterly, 35, 1, 237-256, 2011.

[38] Makkonen H., Pohjola M., Olkkonen R., Koponen A., Dynamic capabilities and firm performance in a financial crisis, Journal of Business Research, 67, 1, 2707-2719, 2014.

[39] Theodosiou M., Kehagias J., Katsikea E., Strategic orientations, marketing capabilities and firm performance: An empirical investigation in the context of frontline managers in service organizations, Industrial Marketing Management, 41, 7, 1058-1070, 2012 .

[40] Santa R., Ferrer M., Bretherton P., Hyland P., Contribution of cross-functional teams to the improvement in operational performance, Team Performance Management: An international Journal, 16, 3/4, 148-168, 2010.

[41] Yeh-Yun L.C., Yi-Ching C.M., Does innovation lead to performance? An empirical study of SMEs in Taiwan, Management Research News, 30, 2, 115-132, 2007.

[42] Chae H.C., Koh C.E., Prybutok V.R., Information technology capability and firm performance: Contradictory findings and their possible causes, Mis Quarterly, 38, 1, 305-326, 2014.

[43] Hardwick P., Dou W., The competitiveness of EU insurance industries, Service Industries Journal, 18, 1, 39-53, 1998.

[44] Selznick P., Foundations of the theory of organization, American Sociological Review, 13, 1, 25-35, 1948.

[45] Duncan R.B., Characteristicsof organizational environments and perceived environmental uncertainties, Administrative Science Quarterly, 17, 3, 313327, 1972.

[46] Emery F., Trist E., The Causal Texture of Organizational Environments, Human Relations, 18, 1, 21-32, 1965. 
[47] Kipley D., Lewis A., Jewe R., Entropy-disrupting Ansoff's five levels of environmental turbulence, Business Strategy Series, 13, 6, 251-262, 2012.

[48] Scott W.R., Organizations rational, natural, and open systems (4th edition), Upper Saddle River, NJ: Prentice-Hall, Inc., 1998.

[49] Rosenbusch N., Rauch A., Bausch A., The Mediating Role of Entrepreneurial Orientation in the Task Environment-Performance Relationship: A MetaAnalysis, Journal of Management, 39, 3, 633-659, 2013.

[50] Child J., Organization structure, environment, and performance: The role of strategic choice, Sociology, $6,1,1-22,1972$.

[51] Bourgeois L.J., On the measurement of organizational slack, Academy of Management Review, 6, 1, 29-39, 1981.

[52] Ling X.L.L., Manufacturing capability development in a changing business environment, Industrial Management \& Data Systems, 100, 6, 261-270, 2000 .

[53] Commander S., Jan S., Business environment, exports, ownership, and firm performance, The Review of Economics and Statistics, 93, 1, 309-337, 2011.

[54] Chi T., Measurement of business environment characteristics in the US technical textile industry: An empirical study, The Journal of the Textile Institute, 100 (6), 545-555, 2009.

[55] González-Benitoa J., da Rochab D., Queiruga D., The environment as a determining factor of purchasing and supply strategy: An empirical analysis of Brazilian firms, International Journal of Production Economics, 124, 1, 1-10, 2010.

[56] Venkatraman N., The concept of fit in strategy research: Toward verbal and statistical correspondence, Academy of Management Review, 14, 3, 423444, 1989.

[57] Porter M., Competitive Strategy, Free Press, New York, NY, 1980.
[58] Cachon G.P., Swinney R., The value of fast fashion: Quick response, enhanced design, and strategic consumer behavior, Management Science, 57, 4, 778-795, 2011

[59] Horne M., Lloyd P., Pay J., Roe P., Understanding the competitive process a guide to effective intervention in the small firms sector, European Journal of Operational Research, 56, 1, 54-66, 1992.

[60] Parnell J.A., Lester D.L., Menefee M.L., Strategy as a response to organizational uncertainty: An alternative perspective on the strategy-performance relationship, Management Decision, 38, 8, 520-530, 2000.

[61] Chang M.H., Peery Jr N.S., Competitiveness of product, firm, industry, and nation in a global business, Competitiveness Review: An International Business Journal, 5, 1, 37-43, 1995.

[62] Buckley P.J., Pass C.L., Prescott K., Measures of international competitiveness: A critical survey* $\dagger$, Journal of Marketing Management, 4, 2, 175-200, 1988.

[63] Momaya K., Cooperation for competitiveness of emerging countries: learning from a case of nanotechnology, Competitiveness Review: An International Business Journal, 21, 2, 152-170, 2011.

[64] Hooley G., Fahy J., Cox T., Beracs J., Fonfara K., Snoj B., Marketing capabilities and firm performance: a hierarchical model, Journal of MarketFocused Management, 4, 3, 259-278, 1999.

[65] Hayes R.H., Wheelwright S.C., Restoring our competitive edge: Competing through manufacturing, New York: John Wiley, 1984.

[66] Rosenzweig E.D., Easton G.S., Tradeoffs in Manufacturing? A Meta-Analysis and Critique of the Literature, Production and Operations Management, 19, 2, 127-141, 2010.

[67] Lawrence W.W., Small business operations strategy: Aligning priorities and resources, Journal of Small Business Strategy, 18, 2, 89-103, 2007.

[68] Amoako-Gyampah K., Meredith J.R., Examining cumulative capabilities in a developing economy, International Journal of Operations \& Production Management, 27 (9), 928-950, 2007. 